\title{
PENINGKATAN PEMBELAJARAN IPA MELALUI MODEL PEMBELAJARAN NYATA DENGAN PENILAIAN AUTENTIK ASSESMENT PADA SISWA KELAS V SDN WOTANSARI TAHUN PELAJARAN $2017 / 2018$
}

\author{
Wahyudi \\ SDN Wotansari Gresik \\ wahyudiw68@gmail.com
}

\begin{abstract}
ABSTRAK
Untuk dapat mempelajari sesuatu dengan baik, kita perlu mendengar, melihat, mengajukan pertanyaan tentangnya dengan membahasnya dengan orang lain. Bukan hanya itu kita juga perlu "mengerjakannya" yakni penggambarkan sesuatu dengan cara kita sendiri, menunjukkan contohnya, mencoba mempraktekkan keterampilan, dan mengerjakan tugas menuntut pengetahuan yang telah kita dapatkan, utamanya dalam hal pembelajaran terhadap siswa. Tujuan penelitian ini adalah untuk mengetahui apakah terjadi peningkatan prestasi belajar pendidikan IPA setelah diterapkan Strategi Pembelajaran Nyata, serta ingin mengetahui pengaruh Strategi Pembelajaran Nyata terhadap peningkatan prestasi dan motivasi belajar materi pelajaran IPA. Penelitian ini menggunakan tindakan (Action research) sebanyak tiga putaran. Setiap putaran terdiri dari empat tahap yaitu : rancangan, kegiatan dan pengamatan, refleksi dan refisi. Sasaran penelitian ini adalah siswa kelas V SDN Wotansari Kecamatan Balongpanggang Kabupaten Gresik Tahun Pelajaran 2017/2018. Data yang diperoleh berupa hasil tes formatif, lembar observasi kegiatan belajar mengajar. Dari hasil analis didapatkan bahwa prestasi belajar siswa mengalami peningkatan dari siklus I sampai III yaitu, siklus I $(75,50 \%)$, siklus II $(82,50 \%)$, siklus III $(100,00 \%)$. Simpulan dari penelitian ini adalah metode pembelajaran Nyata dapat berpengaruh positif terhadap prestasi dan motivasi belajar Siswa kelas V SDN Wotansari Kecamatan Balongpanggang Kabupaten Gresik Tahun Pelajaran 2017/ 2018., serta Strategi ini dapat digunakan sebagai salah satu alternative pembelajaran IPA.
\end{abstract}

Kata Kunci: IPA, Pembelajaran Nyata

\section{ABSTRACT}

In order to learn something well, we need to hear, see, ask questions about it by discussing it with others. Not only that we also need to "do it" that is describing something in our own way, showing the example, trying to practice the skills, and doing the task of demanding the knowledge we have gained, especially in terms of learning to students. The purpose of this study is to determine whether there is an increase in learning achievement of science education after applied Real Learning Strategy, and want to know the influence of Real-Learning Strategy to increase achievement and motivation to learn science lesson materials. This study uses action (Action research) as much as three rounds. Each round consists of four stages: design, activity and observation, reflection and refission. Target of this research is student of class $V$ SDN Wotansari District Balongpanggang Gresik Regency Lesson Year 2017/2018. Data obtained in the form of formative test results, observation sheet of teaching and learning activities. From the analyst's result, it is found that the students' learning achievement has increased from cycle I to III that is, cycle I $(75,50 \%)$, cycle II $(82,50 \%)$, cycle III $(100,00 \%)$. The conclusion of this research is real learning method can have a positive effect on the achievement and motivation of learning Grade V students of SDN Wotansari, Balongpanggang Subdistrict, Gresik Sub-Province, Lesson 2017 / 2018. This strategy can be used as an alternative to science learning.

Keywords: Science, Real Learning 


\section{PENDAHULUAN}

Rendahnya mutu pendidikan pada setiap jenjang dan satuan pendidikan, khususnya pendidikan dasar dan menengah. Berbagai usaha telah dilakukan untuk meningkatkan mutu pendidikan nasional, antara lain melalui berbagai pelatihan dan peningkatan kualitas guru, penyempurnaan prasarana pendidikan lainnya, dan peningkatan mutu manajemen pendidikan sekolah. Namun demikian, berbagai indikator mutu pendidikan belum menunjukkan peningkatan yang merata. Menurut Piaget (dalam Nasution, 2000) mengemukakan bahwa, proses berpikir manusia berkembang secara bertahap, dari berpikir konkrit ke abstrak melalui 4 periode. Keempat periode tersebut adalah (a) periode sensori motor (0-2 tahun), (b) periode pra operasional (2-7 tahun), (c) periode operasi konkrit (7-12 tahun), dan (d) periode operasi formal (11-12 tahun ke atas).

Dari tahap perkembangan tersebut nampak bahwa pembelajaran yang diberikan kepada siswa di Sekolah telah berada pada tingkat pemikiran operasi formal. Pelajaran IPA adalah pelajaran tertinggi, terpenting

Diantara faidah pelajaran IPA adalah mengantarkan anak menjadi anak yang belajar realistik Pendidikan mempunyai peran yang sangat penting dalam mempersiapkan sumber daya manusia yang berkualitas. Perwujudan masyarakat berkualitas menjadi tanggung jawab pendidikan, terutama dalam mempersiapkan peserta didik menjadi subyek yang makin berperan menampilkan keunggulan dirinya yang tangguh, kreatif, mandiri dan profesional pada bidangnya masing-masing.

Tilaar yang dikutip Mulyasa (2002: 20) mengemukakan bahwa: Pendidikan nasional dewasa ini sedang dihadapkan pada empat krisis pokok, yang berkaitan dengan kuantitas, relevansi atau efisiensi eksternal, elitisme, dan manajemen. Lebih lanjut dikemukakan bahwa sedikitnya ada tujuh masalah pokok sistem pendidikan nasional: (1) menurunnya akhlak dan moral peserta didik, (2) pemerataan kesempatan belajar, (3) masih rendahnya efisiensi internal sistem pendidikan, (4) status kelembagaan, (5) manajemen pendidikan yang tidak sejalan dengan pembangunan nasional, dan (6) sumber daya yang belum profesional.

Para pendidik menyadari bahwa IPA bukanlah termasuk bidang studi yang mudah bagi kebanyakan siswa. IPA sering di keluhkan sebagai bidang studi yang sulit dan membosankan. Menurut Soedjadi (1991: 5) bahwa Faktor yang mempengaruhi mutu pendidikan di antaranya adalah: (1) masukan / input; (2) masukan instrumen; dan (3) lingkungan. Selanjutnya dikatakan bahwa masukan instrumen yang meliputi pendidikan, sarana, dan kurikulum dalam arti luas serta 
evaluasi hasil belajar, dipandang sebagai faktor dominan yang memiliki pengaruh besar. Dalam meningkatkan mutu pendidikan hanya mungkin dicapai dengan meningkatkan mutu proses pendidikan yang didalamnya terdapat interaksi antara siswa, guru, sarana, kurikulum, evaluasi dan lingkungan. Dari beberapa faktor tersebut dapat bersama-sama atau sendiri-sendiri mempengaruhinya. Artinya hasil belajar yang rendah tidak hanya dipengaruhi oleh salah satu faktor saja.

Menurut Soedjadi

bahwa bukan sesuatu yang mustahil rendahnya hasil belajar dikarenakan materi kurikulum yang terlalu berat, metode pembelajaran yang tidak tepat, sarana pembelajaran yang tidak mendukung, atau lingkungan sekolah yang tidak memungkinkan proses pembelajaran berjalan normal. Misalnya, perpustakaan sederhana, dan sarana laboratorium yang dimiliki kurang memadai. Akibat keterbatasanketerbatasan tersebut sebagian besar pembelajaran dilaksanakan secara tradisional/konvensional, sehingga dalam waktu relatif singkat dapat menyajikan dan menyelesaikan bahan ajar yang cukup banyak melalui ceramah. Hal ini menyebabkan pelajaran IPA termasuk pelajaran yang kurang diminati siswa.

Berdasarkan kenyataan di lapangan tersebut, salah satu cara untuk dapat meningkatkan prestasi belajar siswa perlu suatu strategi atau pemilihan model pembelajaran yang tepat. Menurut Carin (1993: 82) yang dikutip oleh Kuswardi mengemukakan Pembelajaran Nyata secara sistematis menuntun dan membantu siswa untuk melalui tahap-tahap pembelajaran tertentu, yang bermaksud untuk melihat hasil belajar dari masing masing tahap. Pembelajaran Nyata adalah salah satu model pembelajaran yang memusat pada guru dan disajikan melalui 5 tahap, yaitu (1) menyampaikan tujuan dan mempersiapkan siswa; (2) mendemonstrasikan pengetahuan; (3) pemberian pelatihan terbimbing; (4) mengecek pemahaman dan memberikan umpan balik; dan (5) memberikan perluasan latihan mandiri. Pembelajaran Nyata secara sistematis menuntun dan membantu siswa melalui langkah-langkah atau tahapan-tahapan tertentu, dan selanjutnya siswa akan aktif bekerja sendiri dengan adanya kegiatan latihan terbimbing dan latihan mandiri. Ini berarti siswa akan mendapat informasi yang jelas dalam mempelajari suatu materi pelajaran.

\section{METODE PENELITIAN}

\section{Rancangan penelitian}

Penelitian ini dilaksanakan melalui tiga tahap, sebagai berikut :

1. Pemberian pre-test, yaitu tes yang dilaksanakan sebelum penerapan model pengajaran langsung untuk 
mengetahui pengetahuan awal siswa.

2. Pelaksanaan pengajaran langsung.

3. Pemberian post-test, yaitu tes yang dilaksanakan setelah pelaksanaan model pengajaran langsung.

Ketiga tahap tersebut mengacu pada rancangan penelitian yang menggunakan desain penelitian "One Group Pre-test and Post-test Design" yang digambarkan pola berikut.

\begin{tabular}{|lll|}
\hline $\mathrm{T}_{1}$ & $\mathrm{X}$ & $\mathrm{T}_{2}$ \\
\hline
\end{tabular}

Keterangan:

$\mathrm{T}_{1}$ : Tes yang dilakukan sebelum menggunakan metode Pembelajaran Nyata

$X$ : Perlakuan dengan menerapkan metode Pembelajaran Nyata

$T_{2}$ : : Tes yang dilakukan setelah menggunakan metode Pembelajaran Nyata

(Sudjana, 1989: 31)

\section{Pelaksanaan penelitian}

\section{Pre-test}

Pre-test dilaksanakan sebelum proses pembelajaran berlangsung dan digunakan untuk mengetahui kemampuan dasar siswa. Hasil pre-test juga digunakan sebagai skor dasar dalam penyekoran.

2. Proses pembelajaran

Proses pembelajaran berlangsung selama 3 kali tatap muka atau 4 jam pelajaran digunakan untuk pre-test dan post-test.

\section{Post-test}

Post-test dilaksanakan pada akhir pembelajaran dan digunakan untuk mengetahui apakah dengan pembelajaran ini dapat meningkatkan hasil belajar siswa

\section{Analisis}

Data yang telah diperoleh akan dianalisis sesuai dengan metode analisis data yang digunakan oleh peneliti.

\section{Tempat dan Waktu Penelitian}

Penelitian mengambil objek berupa model pembelajaran pada mata pelajaran IPA kelas $\mathrm{V}$ di SD Negeri Wotansari Balongpanggang Gresik. Sedangkan waktu pelaksanaanya pada bulan Nopember 2017

\section{Populasi penelitian}

Sumadi (2000: 81) berpendapat bahwa generalisasi dari sampel ke populasi mengandung resiko bahwa akan terdapat kekeliruan atau ketidak tepatan, karena sampel tidak akan mencerminkan secara tepat populasinya. Makin tidak sama sampel itu dengan populasinya, maka makin besar pula kemungkinan kekeliruan dalam generalisasi itu.

Pada penelitian ini ditentukan sebagai populasi penelitian adalah siswa kelas V SD Negeri Wotansari Balongpanggang Gresik sebanyak 24 siswa 


\section{Sampel Penelitian}

Sampel adalah sebagai bagian dari populasi, sebagai contoh (master) yang diambil dengan menggunakan cara-cara tertentu. Masalah sampel dalam suatu penelitian timbul disebabkan hal berikut.

1. Penelitian bermaksud mereduksi objek penelitian sebagai akibat dari besarnya jumlah populasi, sehingga harus meneliti sebagian saja dari populasi.

2. Penelitian bermaksud mengadakan generalisasi dari hasil-hasil kepenelitiannya, dalam arti mengenakan kesimpulankesimpulan kepada objek, gejala, atau kejadian yang lebih luas (Hadi, 1980: 70).

Adapun sampel yang digunakan dalam penelitian ini adalah kelas $\mathrm{V}$ SD Negeri

Wotansari Balongpanggang Gresik yang berjumlah 24 siswa, pengambilan sampel dengan teknik purposif sampling
Pengembangan Instrumen Penelitian

Selain disusun dan dikembangkan perangkat pembelajaran, dalam penelitian ini juga dikembangkan instrumen penelitian. Proses pengembangan dilakukan bersamaan dengan perangkat pembelajaran maka ada beberapa kelemahan yang ditemui di antaranya adalah instrumen yang dikembangkan langsung digunakan pada saat pengembangan perangkat sehingga kevalidan instrumen belum terjamin, jadi apabila digunakan untuk mengambil dat ada kemungkinan data yang diambil jadi tidak sesuai (kacau).

Sesuai jenis data yang ingin diperoleh dalam penelitian, maka instrumen yang dikembangkan adalah lembar pengamatan siswa dan tes hasil belajar. Sementara format instrumen penelitian dan lembar validasi yang sudah ada dengan revisi kecil (diadopsi dari Asmara, 2000).

\section{Lembar Respon Siswa}

Tabel 1. Kisi-kisi Respon Siswa

\begin{tabular}{|c|l|c|c|}
\hline Variabel & \multicolumn{1}{|c|}{ Indikator } & Jumlah Item & Nomor Item \\
\hline $\begin{array}{c}\text { Respon } \\
\text { Siswa }\end{array}$ & $\begin{array}{l}\text { 1. Senang terhadap Pembelajaran Nyata } \\
\text { 2. Membaca atau menulis yang relevan } \\
\text { dengan KBM }\end{array}$ & 2 & 1,2 \\
& $\begin{array}{l}\text { 3. Hambatan dalam Pembelajaran Nyata } \\
\text { 4. Menanggapi pendapat atau } \\
\text { pertanyaan orang lain }\end{array}$ & 2 & 5,4 \\
& $\begin{array}{l}\text { 5. Berdiskusi atau tanyajawab antara } \\
\text { siswa dan guru }\end{array}$ & 2 & 7,8 \\
\hline
\end{tabular}


Untuk menguji validitas tes respon siswa ini juga dilakukan dengan validitas isi yaitu dengan melihat indikator-indikator yang dikembangkan, apakah indikatorindikator itu benar indikator respon siswa. Selanjutnya melihat apakah tes yang dikembangkan itu benar untuk mengukur indikator-indikator tersebut. Kemudian untuk mengetahui apakah masing-masing butir memiliki dukungan yang signifikan terhadap skor total keseluruhan butir dilakukan dengan mengkorelasikan skor masing-masing butir dengan skor total keseluruhan butir.

\section{Tes Hasil Belajar}

Pengujian keabsahan instrumen hasil belajar untuk mengetahui kualitas instrumen terutama dari segi validitas dan reliabilitasnya. Jenis validitas yang digunakan dalam penelitian ini adalah validitas isi. Pemilihan validitas ini didasarkan pada argumentasi Tuckman (1978) bahwa jenis validitas yang relevan untuk mengukur prestasi akademik adalah validitas isi sebab validitas ini memiliki keterkaitan dengan tujuan khusus pembelajaran dan materi pembelajaran.

Tes kemampuan awal dan tes perolehan belajar memiliki bentuk, bobot, waktu mengerjakan tes psikomotor dan cara pemberian skor yang sama, perbedaannya terletak pada tes awal tanpa ada pemodelan. Oleh karena itu prosedur pengembangan dan pengujian keandalan isi tes psikomotor hanya difokuskan pada tes psikomotor perolehan belajar, dan selanjutnya tes ini dapat digunakan untuk mengukur kemampuan awal siswa.

Tolak ukur dalam pengujian butir-butir tes perolehan belajar adalah tujuan khusus pembelajaran. Rumusan tujuan pembelajaran dalam penelitian ini berpedoman pada Kurikulum KTSP SD tahun 2006. Hal ini dilakukan agar tidak menyimpang dari kurikulum yang digunakan oleh guru-guru dan perancang program saat ini. Aspek tes dikatakan kesahihan jika tes itu dapat mengukur apa yang seharusnya diukur sesuai dengan maksud rancangan pembuatan tes. aspek butir tes disusun sebanyak 10 butir, dikonsultasikan kepada guru bidang studi IPA untuk mengetahui apa aspek butir-butir tes itu sudah layak digunakan untuk mengukur unjuk kerja siswa sesuai dengan tujuan. Setelah dikonsultasikan dengan guru IPA dilakukan revisi untuk memperbaiki butir-butir yang masih memerlukan perbaikan. Setelah dilakukan revisi atau perbaikan butirbutir tes.

\section{METODE PENGUMPULAN DATA}

\section{Metode pengumpulan data respon siswa}

Respon siswa ditujukan kepada 24 siswa yang sudah dipilih menjadi sampel. Setiap siswa diberi angket respon siswa selama pembelajaran 
berlangsung. Untuk memperoleh data respon siswa dilakukan penyebaran angket sebanyak 10 butir angket.

\section{Metode pengumpulan data hasil belajar}

Untuk memperoleh data hasil belajar siswa pada pokok bahasan praktek IPA, kepada siswa diberikan tes sesudah kegiatan pembelajaran (post-test). Analisis data hasil belajar siswa secara deskriptif bertujuan untuk mendeskripsikan ketuntasan hasil belajar siswa. Data yang yang dianalisis untuk mendeskripsikan ketuntasan hasil belajar siswa adalah data post-test. Sesuai dengan ketentuan ketuntasan belajar berdasarkan petunjuk pelaksanaan kurikulum KBK, seorang siswa dinyatakan tuntas belajar apabila memilki daya serap $\geq 65 \%$. Sedangkan ketuntasan hasil belajar secara klasikal jika dalam suatu kelas terdapat paling sedikit $85 \%$ siswa di kelas tersebut telah tuntas belajar.

\section{TEKNIK ANALISIS DATA}

\section{Data respon siswa}

Untuk memperoleh data respon siswa dilakukan observasi terhadap siswa selama pembelajaran berlangsung. Data dikumpulkan dengan cara melakukan penilaian dengan rumus :

$$
\frac{\text { Nilai yang diperoleh }}{\text { Jumlah skor tertinggi }} \times 10
$$

\section{Data hasil belajar}

Untuk memperoleh data kemampuan awal siswa, kepada siswa diberikan tes sebelum kegiatan pembelajaran berlangsung (pre-test) dengan menggunakan instrumen tes hasil belajar dan di uji dengan uji tanda yaitu:

$\mathrm{p}(\mathrm{X} \leq \mathrm{x})=\Sigma \mathrm{b}(\mathrm{x} ; \mathrm{n}, \mathrm{p})=\Sigma \mathrm{b}(\mathrm{x} ; \mathrm{n}, 1 / 2)$

Untuk memperoleh data hasil belajar siswa, kepada siswa diberikan tes sesudah kegiatan pembelajaran berlangsung (post-test) dengan menggunakan instrumen tes hasil belajar dan hasil di uji dengan uji $t$ tanda sebagai berikut: $p(X \leq x)=\Sigma b$ $(x ; n, p)=\Sigma b(x ; n, 1 / 2)$

\section{HASIL PENELITIAN DAN PEMBAHASAN}

1. Data hasil Analisis pre test dan post test

Setelah data pre test dan post test didapatkan, maka langkah selanjutnya adalah membandingkan antara hasil pre test dan post test tersebut. Hal ini dapat dilihat pada tabel berikut :

Tabel 2. Hasil Analisis Pre Test dan Post Test Melalui Uji Tanda

\begin{tabular}{|c|c|c|c|c|}
\hline No & Pre Test (X) & Post Test (Y) & Arah Perbedaan & Tanda $\left(\mathbf{X}_{\mathbf{i}}-\mathbf{Y}_{\mathbf{i}}\right)$ \\
\hline 1 & 63 & 69 & $\mathrm{X}<\mathrm{Y}$ & + \\
\hline 2 & 65 & 72 & $\mathrm{X}<\mathrm{Y}$ & + \\
\hline 3 & 60 & 70 & $\mathrm{X}<\mathrm{Y}$ & + \\
\hline
\end{tabular}




\begin{tabular}{|c|c|c|c|c|}
\hline No & Pre Test (X) & Post Test (Y) & Arah Perbedaan & Tanda $\left(\mathbf{X}_{\mathbf{i}}-\mathbf{Y}_{\mathbf{i}}\right)$ \\
\hline 4 & 71 & 79 & $\mathrm{X}<\mathrm{Y}$ & + \\
\hline 5 & 66 & 72 & $\mathrm{X}<\mathrm{Y}$ & + \\
\hline 6 & 68 & 75 & $\mathrm{X}<\mathrm{Y}$ & + \\
\hline 7 & 63 & 69 & $\mathrm{X}<\mathrm{Y}$ & + \\
\hline 8 & 65 & 72 & $\mathrm{X}<\mathrm{Y}$ & + \\
\hline 9 & 60 & 70 & $\mathrm{X}<\mathrm{Y}$ & + \\
\hline 10 & 71 & 79 & $\mathrm{X}<\mathrm{Y}$ & + \\
\hline 11 & 66 & 72 & $\mathrm{X}<\mathrm{Y}$ & + \\
\hline 12 & 68 & 75 & $\mathrm{X}<\mathrm{Y}$ & + \\
\hline 13 & 63 & 69 & $\mathrm{X}<\mathrm{Y}$ & + \\
\hline 14 & 65 & 72 & $\mathrm{X}<\mathrm{Y}$ & + \\
\hline 15 & 60 & 70 & $\mathrm{X}<\mathrm{Y}$ & + \\
\hline 16 & 71 & 79 & $\mathrm{X}<\mathrm{Y}$ & + \\
\hline 17 & 66 & 72 & $\mathrm{X}<\mathrm{Y}$ & + \\
\hline 18 & 68 & 75 & $\mathrm{X}<\mathrm{Y}$ & + \\
\hline 19 & 63 & 69 & $\mathrm{X}<\mathrm{Y}$ & + \\
\hline 20 & 65 & 72 & $\mathrm{X}<\mathrm{Y}$ & + \\
\hline 21 & 60 & 70 & $\mathrm{X}<\mathrm{Y}$ & + \\
\hline 22 & 71 & 79 & $\mathrm{X}<\mathrm{Y}$ & + \\
\hline 23 & 66 & 72 & $\mathrm{X}<\mathrm{Y}$ & + \\
\hline 24 & 68 & 75 & $\mathrm{X}<\mathrm{Y}$ & + \\
\hline & & & & + \\
\hline
\end{tabular}

Kolom akhir berisikan tanda $\left(\mathrm{X}_{\mathrm{i}}\right.$ $-Y_{i}$ ) yang memebrikan $h=0$ untuk tanda yang terjadi paling sedikit, ialah tanda negatif. Dengan $\mathrm{n}=24$ dan $\alpha \quad 0,05$ dari tabel nilai kritis $h$ untuk uji tanda (Sudjana, 1992: 448) didapat $h=17$. dari pengamatan diperoleh $\mathrm{h}=0$ dan ini lebih kecil dari 17. Jadi hipotesis berbunyi Ho ditolak dan Hi diterima. Hal ini menunjukkan bahwa ada peningkatan hasil belajar siswa setelah menerapkan Pembelajaran Nyata.

Jadi hipotesis berbunyi "Ada peningkatam hasil belajar siswa setelah mengikuti pembelajaran praktek IPA dibandingkan dengan hasil sebelum menerapkan Pembelajaran Nyata".

\section{Data Hasil Analisis Respon Siswa}

Tabel 3. Tabel hasil respon siswa

\begin{tabular}{|c|c|c|c|}
\hline No & Uraian & $\begin{array}{l}\text { Jumlah } \\
\text { Jawaban }\end{array}$ & Prosentase \\
\hline 1. & $\begin{array}{l}\text { Setelah melaksanakan kegiatan Pembelajaran } \\
\text { Nyata bagaimana perasaannmu } \\
\text { a. bangga } \\
\text { b. biasa saja } \\
\text { c. tidak bangga }\end{array}$ & $\begin{array}{c}32 \\
4 \\
-\end{array}$ & $\begin{array}{c}88.88 \\
11.11 \\
-\end{array}$ \\
\hline
\end{tabular}




\begin{tabular}{|c|c|c|c|}
\hline No & Uraian & $\begin{array}{c}\text { Jumlah } \\
\text { Jawaban }\end{array}$ & Prosentase \\
\hline 2. & $\begin{array}{l}\text { Apakah petunjuk Pembelajaran Nyata yang } \\
\text { diberikan oleh guru cukup jelas? } \\
\text { a. jelas } \\
\text { b. kurang jelas } \\
\text { c. tidak jelas }\end{array}$ & $\begin{array}{c}32 \\
4 \\
-\end{array}$ & $\begin{array}{c}88.88 \\
11.11 \\
-\end{array}$ \\
\hline 3. & $\begin{array}{l}\text { Apakah jalannya pelaksanaan Pembelajaran Nyata } \\
\text { menurut Anda lancar? } \\
\text { a. lancar } \\
\text { b. kurang lancar } \\
\text { c. tidak lancar }\end{array}$ & $\begin{array}{c}26 \\
4 \\
6\end{array}$ & $\begin{array}{c}72.22 \\
11.111 \\
16.66\end{array}$ \\
\hline 4. & $\begin{array}{l}\text { Bagaimana tanggapan Anda terhadap pelaksanaan } \\
\text { Pembelajaran Nyata yang dilakukan } \\
\text { a. menarik } \\
\text { b. kurang menarik } \\
\text { c. tidak menarik }\end{array}$ & $\begin{array}{c}30 \\
4 \\
1\end{array}$ & $\begin{array}{c}83.33 \\
16.66 \\
-\end{array}$ \\
\hline 5 & $\begin{array}{l}\text { Apakah bahasa atau kalimat yang digunakan oleh } \\
\text { guru pembimbingdapat mudah dipahami? } \\
\text { a. mudah dipahami } \\
\text { b. kurang dapat dipahami } \\
\text { c. tidak dapat dipahami }\end{array}$ & $\begin{array}{c}28 \\
6 \\
2\end{array}$ & $\begin{array}{c}77.77 \\
16.66 \\
5.55\end{array}$ \\
\hline 6 & $\begin{array}{l}\text { Menurut pendapat Anda Pembelajaran Nyata } \\
\text { sesuai dengan diharapkan Anda } \\
\text { a. ya } \\
\text { b. kadang-kadang } \\
\text { c. tidak }\end{array}$ & $\begin{array}{c}34 \\
2 \\
-\end{array}$ & $\begin{array}{c}94.44 \\
5.55 \\
-\end{array}$ \\
\hline 7 & $\begin{array}{l}\text { Apakah Anda mengalami hambatan dalam } \\
\text { pelaksanaan Pembelajaran Nyata yang diterapkan } \\
\text { a. tidak mengalami } \\
\text { b. kadang-kadang } \\
\text { c. mengalami hambatan }\end{array}$ & $\begin{array}{c}20 \\
6 \\
10\end{array}$ & $\begin{array}{l}55.55 \\
16.66 \\
27.77\end{array}$ \\
\hline 8 & $\begin{array}{l}\text { Apakah Anda mengharapkan kelanjutan dan } \\
\text { pelaksanaan kegiatan Pembelajaran Nyata ini } \\
\text { a. masih mengharapkan } \\
\text { b. pikir-pikir } \\
\text { c. tidak mengharapkan }\end{array}$ & $\begin{array}{c}32 \\
4 \\
-\end{array}$ & $\begin{array}{c}88.88 \\
11.11 \\
-\end{array}$ \\
\hline 9. & $\begin{array}{l}\text { Apakah anda senang dengan pelaksanaan } \\
\text { Pembelajaran Nyata? } \\
\text { a. Senang sekali } \\
\text { b. Senang } \\
\text { c. Kurang senang }\end{array}$ & $\begin{array}{c}30 \\
6 \\
- \\
\end{array}$ & $\begin{array}{c}83.33 \\
16.66 \\
- \\
\end{array}$ \\
\hline 10. & $\begin{array}{l}\text { Dengan waktu yang tersedia bagaimana } \\
\text { tanggapan Anda? } \\
\text { a. memadai } \\
\text { b. cukup memadai } \\
\text { c. kurang memadai }\end{array}$ & $\begin{array}{c}2 \\
20 \\
14\end{array}$ & $\begin{array}{c}5.55 \\
55.55 \\
38.88\end{array}$ \\
\hline
\end{tabular}




\section{Analisis Data Hasil Penelitian}

Setelah data terkumpul, langkah selanjutnya adalah menganalisis data. Analisis data merupakan hal yang penting dalam suatu penelitian karena dari analisis inilah akan diketahui hasil penelitian yang telah dilakukan. Oleh karena itu dalam mengenalisis data harus dilakukan secara tepat dan teliti, sebab kekeliruan dalam pengumpulan data berakibat kesalahan dalam menarik kesimpulan.

Adapun rincian analisis data tersebut adalah sebagai berikut:

a. Hasil belajar siswa setelah mengikuti pembelajaran IPA pokok bahasan praktek IPA dengan menerapkan Pembelajaran Nyata mengalami peningkatan dibandingkan dengan hasil sebelum menerapkan Pembelajaran Nyata

Kolom akhir berisikan tanda $\left(X_{i}-Y_{i}\right)$ yang memebrikan $\mathrm{h}=0$ untuk tanda yang terjadi paling sedikit, ialah tanda negatif. Dengan $n=24$ dan $\alpha$ 0,05 dari tabel nilai kritis $\mathrm{h}$ untuk uji tanda (Sudjana, 1992: 448) didapat $\mathrm{h}=$ 17. dari pengamatan diperoleh $\mathrm{h}=$ 0 dan ini lebih kecil dari 17. Jadi hipotesis berbunyi Ho ditolak dan Hi diterima. Hal ini menunjukkan bahwa ada peningkatan hasil belajar siswa setelah menerapkan Pembelajaran Nyata.
Jadi hipotesis berbunyi "Ada peningkatam hasil belajar siswa setelah mengikuti pembelajaran praktek IPA dengan menerapkan Pembelajaran Nyata dibandingkan dengan hasil sebelum menerapkan Pembelajaran Nyata"

b. Respon siswa dalam Pembelajaran Nyata

Dari hasil angket yang telah dilakukan diperoleh sejumlah jawaban siswa mengenai respon siswa selama pelaksanaan strategi Pembelajaran Nyata. Dalam kegiatan pembelajaran perlakuan yang pertama dalam dapat dikatakan berhasil dengan baik, karena siswa mempunyai respon yang positif selama pembelajaran berlangsung.

\section{Pembahasan Hasil}

Kolom akhir berisikan tanda $\left(X_{i}-Y_{i}\right)$ yang memberikan $h=0$ untuk tanda yang terjadi paling sedikit, ialah tanda negatif. Dengan $\mathrm{n}=42 \alpha 0,05$ dari tabel nilai kritis $h$ untuk uji tanda (Sudjana, 1992: 448) didapat $\mathrm{h}=$ 17. dari pengamatan diperoleh $\mathrm{h}=$ 0 dan ini lebih kecil dari 17. Jadi hipotesis berbunyi Ho ditolak dan Hi diterima. Hal ini menunjukkan bahwa ada peningkatan hasil belajar siswa setelah menerapkan Pembelajaran Nyata.

Jadi hipotesis berbunyi "Ada peningkatam hasil belajar siswa 
setelah mengikuti pembelajaran praktek IPA dengan menerapkan Pembelajaran Nyata dibandingkan dengan hasil sebelum menerapkan

Pembelajaran Nyata".

Berdasarkan hasil penelitian, maka diketahui siswa yang menggunakan pembelajaran bidang studi IPA pada tingkat tinggi, selanjutnya dibuat rencana untuk membantu dalam hal penyelesaiannya, salah satu caranya adalah dengan menggunakan Pembelajaran Nyata.

Adapun data dari hasil penelitian ini ialah: (1) Dari pre test terdapat siswa yang belum memahami belajar bidang studi IPA, tetapi setelah mendapat latihan strategi Pembelajaran Nyata maka secara bertahap dapat memahami, (2) Ada perubahan hasil belajar dengan adanya perlakuan.

Dari keterangan ini terlihat bahwa siswa telah memperoleh hasil belajar yang lebih baik tentang pelaksanaan Pembelajaran Nyata sehingga akhirnya dapat memahami pembelajaran dalam bidang studi IPAi. Hal ini sesuai dengan pendapat Soetarlina Soekardji (1985: 99), “Kadang-kadang pencatatan data berlaku saja sudah menimbulkan berubahan frekuensinya'. Dari penelitain yang dilakukan dan berdasarkan hasil analisis yang telah terbukti bahwa pengaruh positif dari pelaksanan Pembelajaran Nyata terhadap bidang studi IPA siswa kelas V SD Negeri Wotansari Balongpanggang Gresik

Dalam pelaksanaan Pembelajaran Nyata tidak terdapat kendala-kendala, baik dari segi tempat maupun suasana latihan, kelancaran latihan, petunjuk kegiatan yang telah diberikan maupun bahasa atau kalimat yang digunakan oleh pembimbing kecuali alokasi waktu yang kurang memadai selama pelaksanaan Pembelajaran Nyata, karena disesuaikan dengan waktu yang ada. Untuk mengatasi masalah waktu pemberian perlakuan dapat dilakukan tidak hanya pada hari-hari efektif sekolah saja namun juga pada hari sekolah, sehingga masalah waktu dapat dihindari atau diatasi.

\section{KESIMPULAN}

1. Ada peningkatam hasil belajar siswa setelah mengikuti pembelajaran langsung dibandingkan dengan hasil sebelum menerapkan Pembelajaran Nyata

2. Siswa mempunyai respon yang positif terbukti dari angket yang disebarkan maka siswa mempunyai rasa senang. 


\section{DAFTAR PUSTAKA}

Arend, R. I. 1997. Classroom Instruction and Management. New york: McGraw-Hill.

Arikunto, S. 2001. Dasar-Dasar Evaluasi Pendidikan. Jakarta: Bumi Aksara.

Arikunto, S. 2002. Prosedur Penelitian. Revisi kelima. Jakarta: Rineka Cipta.

Budayasa, I. K. 1998. Teori Belajar Perilaku. Buku ajar yang dikembangkan dalam rangka penelitian berjudul Restrukturisasi Kurikulum PBM dan Peningkatan Hubungan IKIP Surabaya dengan Universitas luar Negeri. Surabaya: PPs. IKIP Surabaya.

Degeng, I Nyoman Sudana. 1989. IImu Pelajaran Taksonomi Variabel. Jakarta: Depdikbud Dikti.

Departemen Pendidikan dan Kebudayaan. 1999. Penyempurnaan/ Penyesuaian Kurikulum Pendidikan Dasar 1994 (suplemen GBPP) Jakarta.

Effendi. 1999. Pengembangan Perangkat Pembelajaran Fisika SLTP Pokok Bahasan Cahaya Berorientasi Model Pembelajaran Nyata. Tesis Magister Pendidikan yang tidak dipublikasikan, Universitas Negeri Surabaya.

Hudojo, Herman. 1988. Mengajar Belajar Matematika. Jakarta: Dirjen Dikti P2LPTK.

Kardi, Soeparman. 1997. Direct Instruction, Penemuan Terbimbing dan Investigasi Kelompok, IKIP Surabaya.
Kuswardi, Yemi. 2001. Penerapan Model Pembelajaran Nyata pada Pokok Bahasan Persamaan Linier dengan Satu Peubah. Tesis Magister Pendidikan yang tidak dipublikasikan, Universitas Negeri Surabaya.

Mulyasa, E. 2000. Kurikulum Berbasis Kompetensi. Jakarta: Bumi Aksara.

Margono. $1997 . \quad$ Metodologi Penelitian Pendidikan. Jakarta: Rineka Cipta.

Nur, M.2000. Pengajaran Langsung. Surabaya: University Press Surabaya.

Rusyan, T., Atang Kusnidar, Zainal Arifin. 1989. Pendekatan dalam Proses belajar Mengajar. Bandung: Remaja Karya.

Soedjadi, R. 1991. Belajar dan Faktorfaktor yang Mempengaruhinya. Cetakan Kedua. Jakarta: Rineka Cipta.

Soekamto, T., Winataputra dan Saripudin, U. 1995. Teori Belajar dan Model-model Pembelajaran. Jakarta: Pusat Antar Universitas Untuk Peningkatan Respon Instruksional Dirjen Dikti Diknas.

Thiagarajan, S \& Semmel, M. M. I. 1974. Instructional Development for Training Teacher of Expentional Children. Bloomington: Indiana University.

Winkel, WS. 1989. Psikologi Pengajaran. Jakarta: Gramedia. 